\title{
Systemic Lupus Erythematosus-associated Thrombocytopenia in Pregnancy: Is Splenectomy Necessary at the Time of Delivery?
}

\author{
${ }^{1}$ Marcello Granate, ${ }^{2}$ Filomena Quaglia, ${ }^{3}$ Patrizio Petrone, ${ }^{4}$ Giuseppe Cerciello, ${ }^{5}$ Corrado Marini, ${ }^{6}$ Pasquale Martinelli
}

\begin{abstract}
Background: Systemic lupus erythematosus (SLE)-associated thrombocytopenia in pregnancy is a rare condition associated with potential harm to the mother, the fetus, and/or newborn, if the thrombocytopenia is severe $\left(<50,000 / \mathrm{mm}^{3}\right)$. Controversy persists regarding the role and the timing of splenectomy in patients with SLE-associated refractory immune thrombocytopenia in pregnancy. This report describes the use of splenectomy at the time of the cesarean section (CS) in a patient with refractory SLE-associated thrombocytopenia.
\end{abstract}

Case report: A 19-year-old gravida 2, para 1 woman with SLEassociated thrombocytopenia diagnosed at age 16 developed a platelet count of $10,000 / \mathrm{mm}^{3}$ at the 18 th week of gestation. She had been asymptomatic until that point, except for a previous spontaneous abortion at the 8th week of gestation in 2008. During this admission she was treated initially with methylprednisolone and enoxaparin, but following an episode of epistaxis she received intravenous immunoglobulin (IVIG). She was discharged home with a platelet count of $52,000 / \mathrm{mm}^{3}$. She was readmitted on the 34th week of gestation with a platelet count of $15,000 / \mathrm{mm}^{3}$ unresponsive to steroids and IVIG; she underwent a CS and an open splenectomy. Following surgery, she continued to receive maintenance dose steroids. She had a partial response to the splenectomy (platelet count on discharge $63,000 / \mathrm{mm}^{3}$ ).

Conclusion: Splenectomy at the time of CS is a safe therapeutic option for women with SLE-associated refractory thrombocytopenia during pregnancy.

Keywords: Antiglycoprotein Ilb/Illa antibodies, Pregnancy, Splenectomy, Systemic lupus erythematosus, Thrombocytopenia.

\footnotetext{
${ }^{1,2}$ Resident, ${ }^{3}$ Director, Clinical Associate Professor and PhD Student, ${ }^{4-6}$ Surgeon

1,2,6 Dipartimento di Ostetricia e Ginecologia, Università degli Studi di Napoli Federico II, Napoli, Italy

${ }^{3}$ Department of Surgery, NYU Winthrop Hospital, Mineola Long Island, New York, USA; Department of Surgery, New York Medical College, Valhalla, New York, USA; Universidad de Las Palmas de Gran Canaria, Spain

${ }^{4}$ Dipartimento di Ematologia, Università degli Studi di Napoli Federico II, Napoli, Italy

${ }^{5}$ Department of Surgery, New York Medical College, Valhalla New York, USA
}

Corresponding Author: Patrizio Petrone, Director, Clinical Associate Professor and PhD Student, Department of Surgery NYU Winthrop Hospital, Mineola Long Island, New York, USA Department of Surgery, New York Medical College, Valhalla, New York, USA; Universidad de Las Palmas de Gran Canaria, Spain Phone: +19143746563, e-mail: patrizio.petrone@gmail.com
How to cite this article: Granate M, Quaglia F, Petrone P, Cerciello G, Marini C, Martinelli P. Systemic Lupus Erythematosus-associated Thrombocytopenia in Pregnancy: Is Splenectomy Necessary at the Time of Delivery? Panam J Trauma Crit Care Emerg Surg 2017;6(3):219-223.

Source of support: Nil

Conflict of interest: None

\section{RESUMEN}

Antecedentes: La trombocitopenia asociada al Lupus Eritematoso Sistémico (LES) en el embarazo es una afección rara asociada con daño potencial a la madre, al feto y/o al recién nacido, si la trombocitopenia es grave $\left(<50.000 / \mathrm{mm}^{3}\right)$. La controversia persiste con respecto al papel y el momento de la esplenectomía en pacientes con trombocitopenia inmune refractaria asociada al LES en el embarazo. Este informe describe el uso de la esplenectomía en el momento de la cesárea (CS) en un paciente con trombocitopenia refractaria asociada al LES.

Caso: Paciente femenina de 19 años de edad, con trombocitopenia asociada a LES diagnosticada a los 16 años, gravida 2, para 1 , desarrolló un recuento de plaquetas de $10.000 / \mathrm{mm}^{3}$ a la $18^{\circ}$ semana de gestación. Hasta ese momento había estado asintomática, excepto por un aborto espontáneo previo a la $8^{\circ}$ semana de gestación en 2008. Durante esta admisión se trató inicialmente con metilprednisolona y enoxaparina pero tras un episodio de epistaxis recibió inmunoglobulinas intravenosas (IVIG). Fue dada de alta con un recuento de plaquetas de $52.000 / \mathrm{mm}^{3}$. Fue readmitida a la $34^{\circ}$ semana de gestación con un recuento de plaquetas de $15.000 / \mathrm{mm}^{3}$ no responde a los esteroides y IVIG. Se sometió a un CS y una esplenectomía abierta. Después de la cirugía, continuó recibiendo dosis de mantenimiento de esteroides. Tuvo una respuesta parcial a la

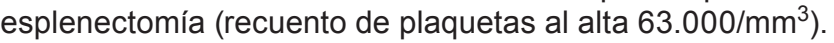

Conclusión: La esplenectomía en el momento del CS es una opción terapéutica segura para las mujeres con trombocitopenia refractaria asociada al LES durante el embarazo.

Palabras clave: Anticuerpos anti - GPIIb / IIla, El embarazo, Esplenectomía, Lupus eritematoso sistémico, Trombocitopenia.

\section{RESUMO}

Antecedentes: A trombocitopenia associada ao Lupus Eritematoso Sistêmico (LES) na gravidez é uma condição rara associada a possíveis danos à mãe, ao feto e / ou ao recém nascido, se a trombocitopenia for grave $\left(<50.000 / \mathrm{mm}^{3}\right)$. A controvérsia persiste em relação ao papel e ao momento da esplenectomia em pacientes com trombocitopenia imune refratária associada ao LES na gravidez. Este relatório descreve o uso de esplenectomia no momento da cesariana (CS) em um paciente com trombocitopenia associada ao LES. 
Caso: Paciente do sexo feminino, 19 anos, com trombocitopenia associada com LES diagnosticado aos 16 anos, grávida 2 a 1 , desenvolveu uma contagem de plaquetas de $10.000 / \mathrm{mm}^{3}$ para a $18^{a}$ semana de gestação. Até então ele tinha sido assintomática, com excepção de um aborto espontâneo antes às 8 semanas de gestação em 2008. Durante esta admissão foi inicialmente tratada com metilprednisolona e enoxaparina mas após um episódio de epistaxe receberam imunoglobulina intravenosa (IVIG). Ele recebeu alta com uma contagem de plaquetas de $52.000 / \mathrm{mm}^{3}$. Ele foi readmitido no $34^{\mathrm{a}}$ semana de gestação com uma contagem de plaquetas de $15.000 / \mathrm{mm}^{3}$ não responde aos esteróides e IVIG. Ele passou por uma CS e uma esplenectomia aberta. Após a cirurgia, ele continuou a receber uma dose de manutenção de esteróides. Ele teve uma resposta parcial a esplenectomia (contagem de plaquetas $63.000 / \mathrm{mm}^{3}$ ).

Conclusão: A esplenectomia no momento do CS é uma opção terapêutica segura para mulheres com trombocitopenia refratária associada ao LES durante a gravidez.

Palavras clave: Anticorpos anti-GPIIb/IIla, Esplenectomia, Gravidez, Lupus eritematoso sistêmico, Trombocitopenia.

\section{INTRODUCTION}

Thrombocytopenia, defined as a platelet count $<150,000$ / $\mathrm{mm}^{3}$, is encountered in 7 to $8 \%$ of normal pregnancies. ${ }^{1}$ This form of thrombocytopenia, defined as gestational thrombocytopenia, is benign because it is not associated with increased bleeding tendency in the mother or with thrombocytopenia in the newborn. Typically, no therapy is required and normal vaginal delivery is the norm. ${ }^{2}$ However, the acute or chronic autoimmune thrombocytopenias of pregnancy, among the SLE-associated thrombocytopenia, may have a significant impact on the mother and/or the fetus/newborn. ${ }^{3,4}$ Therefore, the rheumatologist and obstetrician treating such patients are confronted with complex therapeutic decisions, including the choice of medications during the pregnancy, the timing and route of the delivery, the possibility of bleeding in the newborn from thrombocytopenia, and in those cases of thrombocytopenia refractory to medical treatment whether splenectomy should be undertaken to correct the immunemediated thrombocytopenia in the pregnant woman. In this case report, we describe our approach to a young pregnant patient with SLE-associated thrombocytopenia refractory to medical treatment, which included splenectomy at the time of the CS, and we outline a potential decision tree based on the pertinent review of the available literature.

\section{CASE REPORT}

The patient is a 19 -year-old woman, gravida 2, para 0 , first diagnosed with SLE in 2006 at age 16 when she had developed thrombocytopenia. At the time of the diagnosis of SLE, she had been treated with bolus IV methylprednisolone with a complete response (platelet count $>150,000$ / $\mathrm{mm}^{3}$ ). She was treated subsequently with $6 \mathrm{mg} /$ day of methylprednisolone for 1 year at which time her platelet count had normalized. She remained asymptomatic with a normal platelet count, and in early 2008 she became pregnant but suffered a spontaneous abortion at the 8th week of gestation. Following this event, she remained asymptomatic. In November 2008, she became pregnant again. At this time, she underwent an extensive hematologic and immunologic workup that showed normal thyroid and liver function tests, positive antinuclear antibodies (ANA), antiextractable nuclear antigen antibodies, normal $\mathrm{C}_{4}$ with decreased $\mathrm{C}_{3}$, increased anticardiolipin [immunoglobulin $\mathrm{M}(\operatorname{IgM})$ ] antibodies, elevated anti$\beta$-glycoprotein, and a platelet count of $204,000 / \mathrm{mm}^{3}$. Vaginal and rectal swabs were negative for Streptococcus agalactiae. She was given hydroxychloroquine, aspirin, and enoxaparin subcutaneously $40 \mathrm{mg} /$ day. Her platelet count remained relatively stable, ranging between 80,000 and $100,000 / \mathrm{mm}^{3}$ until the 18 th week of gestation when her blood work revealed a platelet count of $11,000 / \mathrm{mm}^{3}$. At this time (February 13, 2009), she was admitted to the outpatient department for further diagnostic workup and for appropriate treatment. Her laboratory workup showed elevated anti-centromere antibodies, ANA with decreased $\mathrm{C}_{3}$ level, normal prothrombin time, partial thromboplastin time, fibrinogen level $(270 \mathrm{mg} / \mathrm{dL})$, and ATIII levels (95\%). Heparin-induced thrombocytopenia was excluded by assaying antiheparin/PF4-antibodies titer. Her hemoglobin and hematocrit were $10.5 \mathrm{~g} / \mathrm{dL}$ and 33\% respectively. She had anti-Ro/SSA and anti-La / SSB antibodies. Her rheumatoid factor was $23 \mathrm{IU} / \mathrm{mL}$ (upper limit of normal 15.9). On February 15, 2009, her platelet count decreased to $9,000 / \mathrm{mm}^{3}$; at this time, she experienced epistaxis. She was treated with eight units of platelet concentrates and the methylprednisolone was increased from 16 to $24 \mathrm{mg}$ /day. In addition, she received IVIG $400 \mathrm{mg} /$ day for 5 days. Her platelet count rose to $52,000 / \mathrm{mm}^{3}$ by March 8,2009 when she was discharged home on methylprednisolone $6 \mathrm{mg}$ /day, hydroxychloroquine, and aspirin. Her interval follow-up examinations confirmed a satisfactory progression of her pregnancy with decreased platelet counts ranging between 20,000 and $25,000 / \mathrm{mm}^{3}$ without any bleeding event (Graph 1 ).

On her 34th week of gestation (May 20, 2009), she was admitted to our department with a treatment plan that included another course of IVIG with pulsed steroids in preparation for an elective CS. However, she failed to respond to the treatment. Based on her failure to respond to the IVIG therapy, the hematology consultant suggested that she should undergo splenectomy at the time of the CS (Graph 2). On June 3, 2009, her platelet count, just before the CS, was $15,000 / \mathrm{mm}^{3}$. She received eight units of platelets before a midline laparotomy through which a transverse segmental CS was done followed immediately by the splenectomy. The intraoperative and postoperative course was 


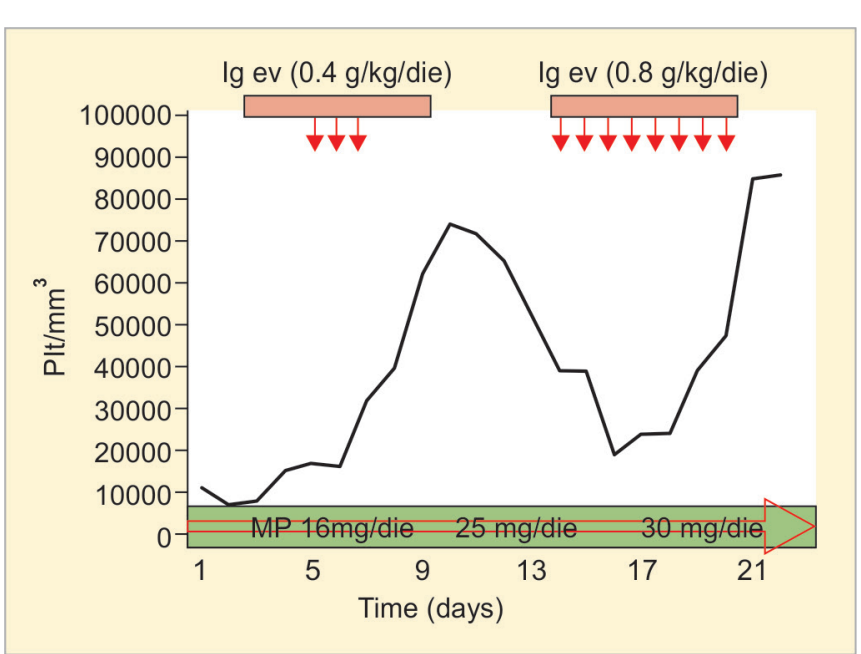

Graph 1: Platelet's trend during IVIG therapy at first hospitalization. MP: Methylprednisolone; Ig: Immunoglobulin; PIt: Platelets

uneventful. Her postoperative platelet count rose to a nadir of $63,000 / \mathrm{mm}^{3}$ on June 10,2009 when she was discharged home. The treatment plan at this time included the use of Rituximab. A healthy newborn with a normal platelet count was delivered via CS. At the last follow-up visit, the patient's platelet count was $>100,000 / \mathrm{mm}^{3}$.

\section{DISCUSSION}

This case report provides the opportunity to review several issues associated with the decision-making process concerning the management of SLE patients who develop thrombocytopenia during the pregnancy.

\section{Systemic Lupus Erythematosus in Pregnancy}

Fertility rate in SLE patients has been reported to be similar to that of the normal population. ${ }^{3}$ Earlier reports recommended that SLE patients avoid or even terminate pregnancy because of the potential negative effects of pregnancy on the course of disease. ${ }^{4,5}$ Some investigators believe that the rate of flares during pregnancy is similar to the rate observed in nonpregnant SLE patients, whereas other investigators suggest that pregnancy may increase disease activity. ${ }^{6,7} \mathrm{~A}$ more recent prospective outcome study of planned pregnancies in patients with SLE shows that if one excludes early spontaneous and induced abortions, patients with SLE can have a live birth rate of $96 \%$ without maternal or neonatal death, although with a high rate of premature births, with a $27 \%$ incidence of modest to moderate lupus flares. ${ }^{8}$ The two most important factors associated with worse fetal outcome in SLE are lupus activity during the pregnancy and the presence of antiphospholipid antibodies (anticardiolipin antibody and lupus anticoagulant). ${ }^{9}{ }^{910}$ Pregnancy in patients with SLE is typically safe, if the disease has been inactive on $20 \mathrm{mg}$ or less of prednisone for at least 1 year. Our patient had been

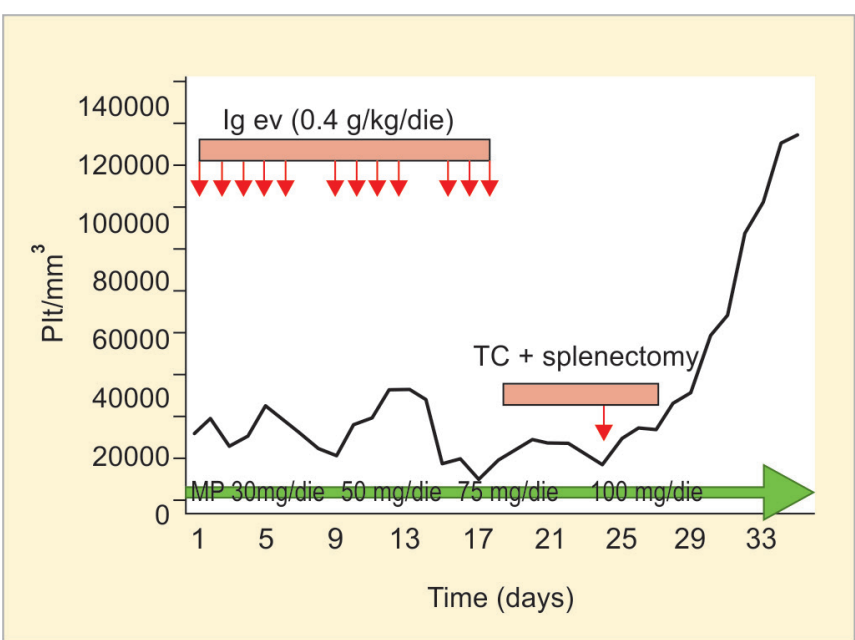

Graph 2: Platelet's trend during IVIG therapy at second hospitalization. MP: Methylprednisolone; Ig: Immunoglobulin; PIt: Platelets; CS: Cesarean section

asymptomatic with normal renal function off steroids for over 1 year; therefore, when she inquired about becoming pregnant again she was advised that a potential pregnancy would not expose her to excessive risks.

\section{Gestational vs SLE-associated Thrombocytopenia}

The overall incidence of thrombocytopenia, defined as a platelet count $<150,000 \mathrm{~mm}^{3}$, in pregnancy varies between 5.1 and $8 \%{ }^{11}$ The most common cause is gestational thrombocytopenia, which typically accounts for more than $75 \%$ of cases. ${ }^{12}$ However, thrombocytopenia is also common in SLE patients and has been reported to be present in $14 \%$ of pregnant SLE patients. ${ }^{13}$ Clearly, several aspects of the thrombocytopenia were present in the patient reported here, such as its preexistence before the pregnancy, the severe degree of the thrombocytopenia, and the response to the steroid treatment in 2006, which suggested an SLE-associated thrombocytopenia instead of gestational thrombocytopenia. Of note, the patient's platelet count during the first trimester remained moderately low but was within the range of values observed before her pregnancy. This is consistent with the available evidence suggesting that pregnancy does not worsen the course of immune-mediated thrombocytopenia. ${ }^{14}$ However, at the time of the second trimester, her platelet count had decreased to $9,000 / \mathrm{mm}^{3}$; at this time she had one episode of bleeding (epistaxis) requiring treatment with IVIG. She had a moderate response to the IVIG with a rise of the platelet count to $52,000 / \mathrm{mm}^{3}$ on discharge from our department, and a decrease to the 20,000s range thereafter.

Should she have been considered to have refractory SLE-associated thrombocytopenia at this time based on the decrease in platelet count while still on medical 
management? Based on the relatively short-lived response to the treatment with IVIG with an almost immediate return of her platelet count to values below 25,000/ $\mathrm{mm}^{3}$, she was unlikely to have a positive response to another course of IVIG, as in fact occurred when she was admitted for the elective CS on the 34th week of gestation. Since she was in the second trimester of pregnancy should she have had a laparoscopic splenectomy at this time to avoid the possible bleeding hazards to her and her fetus associated with platelet concentrations below a critical level? There has been at least one case report suggesting that laparoscopic splenectomy in the second trimester of pregnancy is a viable therapeutic option for the treatment of refractory immune-mediated thrombocytopenia in pregnancy. ${ }^{14}$ Furthermore, if laparoscopic splenectomy is performed in the second trimester, the patient is very likely to have a spontaneous delivery.

Our hematology consultant felt that it was safe to allow the patient to continue her pregnancy with a platelet count above $20,000 / \mathrm{mm}^{3}$ and that the patient should undergo delivery via CS after the 34th week of gestation after another course of IVIG, if needed. Due to the inadequate response to the repeated course of IVIG, the hematologist advised that the patient should have an open splenectomy at the time of the CS, after transfusion of platelet concentrates to raise the platelet count above $50,000 / \mathrm{mm}^{3}$. Obviously, three issues are raised by the suggestions made by our hematologist: First, the route of delivery; second, the need and timing for splenectomy; third, the overall outcome of splenectomy for thrombocytopenia associated with SLE and the ability to predict the response to the splenectomy in this patient.

The first question about the route of delivery concerns whether a vaginal delivery instead of the CS could have been done after having increased the platelet count above $50,000 / \mathrm{mm}^{3}$ with transfusion of platelets, delaying the splenectomy to a later time after having observed whether the pregnancy itself had an effect on the patient's thrombocytopenia. In the past, it has been common practice to perform CS on mothers with SLE-associated thrombocytopenia to decrease the potential risk on intracranial hemorrhage caused by a vaginal delivery. ${ }^{15,16}$ It has also been suggested that fetal platelet count $<50,000 /$ $\mathrm{mm}^{3}$ may place the fetus at greater risk of intracranial hemorrhage; therefore, CS should be considered in these instances. ${ }^{10}$ Based on the potential relationship between fetal platelet count and the risk of intracranial bleeding, some authors have suggested the use of either fetal scalp blood sampling or percutaneous umbilical vein sampling to determine the fetal platelet count and to select the mode of delivery. ${ }^{17,18}$ However, more recent data do not support a correlation between fetal scalp platelet count and neonatal platelet count at birth and they provide evidence that percutaneous umbilical vein sampling is associated with a high incidence of complications. ${ }^{19}$ Furthermore, the universal application of CS delivery to pregnant patients with immune-mediated thrombocytopenia has not been shown to decrease the incidence of intraventricular hemorrhage. ${ }^{20}$ A review of 601 infants born to women with immune thrombocytopenia showed that severe neonatal thrombocytopenia was present in 72/601 (12\%) and that the neonatal intracranial hemorrhage is extremely rare and unrelated to the mode of delivery. ${ }^{20}$

The second issue is whether splenectomy was indicated at the time of the CS at the 34th week of gestation or whether the patient should have had the splenectomy in the second trimester. The role and timing of splenectomy in pregnant SLE patients with thrombocytopenia refractory to medical treatment, including IVIG, remains controversial because of the very limited literature available to support an evidence-based approach to these patients. One report, which includes five patients with immune thrombocytopenic purpura (ITP) treated with splenectomy at the time of CS in the third trimester of gestation, proposes that splenectomy following CS is a very good option for mothers with severe resistant ITP. $^{21}$ This approach is also supported by another case report suggesting that splenectomy combined with CS at the 34th week of gestation can provide remission of ITP. ${ }^{22}$ However, another case report that supports laparoscopic splenectomy during the second trimester has a therapeutic option since this approach may afford the patient the possibility of vaginal delivery in the third trimester. ${ }^{14}$ Obviously, it is not possible to identify the "best" evidence-based approach to these patients based on occasional case reports. However, since laparoscopic splenectomy is safe in the second trimester, it seems reasonable to adopt this approach that may prevent the need for a CS at the term of pregnancy.

The third issue regards whether there is evidence to support the efficacy of splenectomy to treat thrombocytopenia associated with SLE and whether there are useful predictors to identify responders vs nonresponders to splenectomy in patients with SLE-associated thrombocytopenia in pregnant and nonpregnant patients. Hall et $\mathrm{al}^{23}$ reviewed the efficacy of splenectomy to treat thrombocytopenia associated with SLE; they concluded that splenectomy is not effective at curing the thrombocytopenia observed in patients with SLE; therefore, they suggest that it should be used only as a very last resort after having exhausted all other therapeutic modalities. However, a more recent review of this issue from the Mayo Clinic shows that splenectomy is effective in treating SLE-associated thrombocytopenia by providing an $88 \%$ early partial or complete response and a $64 \%$ sustained response rate. ${ }^{24}$ The pathogenesis of 
thrombocytopenia in SLE is believed to result from either increased platelet clearance mediated by antiplatelet autoantibodies [antiglycoprotein (GP)IIb/IIIa antibodies], a mechanism similar to that observed in ITP or by autoantibodies to thrombopoietin receptor (TPOR), which inhibits thrombopoietin-dependent megakaryogenesis. The presence of anti-TPOR antibodies has been associated with the lack of response to IVIG and may be predictive of a poor response to splenectomy in patients with SLEassociated thrombocytopenia. ${ }^{25}$

\section{CONCLUSION}

Based on a thorough review of the available literature, we conclude that patients with SLE-associated thrombocytopenia refractory to medical treatment during pregnancy should undergo testing for the presence of anti-GPIIb/IIIa and anti-TPOR antibodies early during their pregnancy. If patients have anti-GPIIb/IIIa and absent anti-TORP antibodies and they fail to respond to IVIG, they should undergo laparoscopic splenectomy in the second trimester of gestation followed by vaginal delivery at completion of gestation. Open splenectomy immediately following CS in the third trimester remains an available, safe choice, if splenectomy has not been done in the second trimester.

\section{REFERENCES}

1. Burrows RF, Kelton JG. Thrombocytopenia at delivery: a prospective survey of 6715 deliveries. Am J Obstet Gynecol 1990 Mar;162(3):731-734.

2. Burrows RF, Kelton JG. Fetal thrombocytopenia its relation to maternal thrombocytopenia. N Engl J Med 1993 Nov;329(20):1463-1466.

3. Fraga A, Mintz G, Orozco J, Orozco JH. Sterility and fertility rates, fetal wastage and maternal morbidity in systemic lupus erythematosus. J Rheumatol 1974;1:293-298.

4. Ellis FA, Bereston ES. Lupus erythematosus associated with pregnancy and menopause. AMA Arch Dermatol Syphilol 1952 Feb;65(2):170-176.

5. Friedman EA, Rutherford JW: Pregnancy and lupus erythematosus. Obstet Gynecol 1956 Nov;8(5):601-610.

6. Lê Thi Huong D, Wechsler B, Vauthier-Brouzes D, Seebacher J, Lefèbre G, Blétry O, Darbois Y, Godeau P, Piette JC. Outcome of planned pregnancies in systemic lupus erythematosus: a prospective study on 62 pregnancies. Br J Rheumatol 1997 Jan;36(7):772-777.

7. Lockshin MD, Reinitz E, Druzin ML, Murrman M, Estes D. Lupus pregnancy. Case-control prospective study demonstrating absence of lupus exacerbation during or after pregnancy. Am J Med 1984 Nov;77(5):893-898.

8. Petri M, Howard D, Repke J. Frequency of lupus flares in pregnancy. The Hopkins lupus pregnancy center experience. Arthritis Rheum 1991 Dec;34(12):1538-1545.
9. Love PE, Santoro SA. Antiphospholipid antibodies: anticardiolpin and the lupus anticoagulant in systemic lupus erythematosus (SLE) and in non-SLE disorders. Ann Intern Med 1990 May;112(9):682-698.

10. Sullivan CA, Martin JN Jr. Management of the obstetric patient with thrombocytopenia. Clin Obstet Gynecol 1995 Sep;38(3):521-534.

11. Shehata N, Burrows R, Kelton JG: Gestational thrombocytopenia. Clin Obstet Gynecol 1999 Jun;42(2):327-334.

12. Levy JA, Murphy LD. Thrombocytopenia in pregnancy. J Am Board Fam Pract 2002 Jul-Aug;15(4):290-297.

13. Lima F, Buchanan NM, Khamashta MA, Kerslake S, Hughes GR. Obstetric outcome in systemic lupus erythematosus. Semin Arthritis Rheum 1995 Dec;25(3):184-192.

14. Griffiths J, Sia W, Shapiro AM, Tataryn I, Turner AR. Laparoscopic splenectomy for the treatment of refractory immune thrombocytopenia in pregnancy. J Obstet Gynaecol Can 2005 Aug;27(8):771-774.

15. Territo M, Finkelstein J, Oh W, Hobel C, Kattlove H. Management of autoimmune thrombocytopenia in pregnancy and in the neonate. Obstet Gynecol 1973 Apr;41(4):579-584.

16. Jones RW, Asher MI, Rutherford CJ, Munro HM. Autoimmune (idiopathic) thrombocytopenia purpura in pregnancy and the newborn. Br J Obstet Gynaecol 1977;84:679-683.

17. Kaplan C, Daffos F, Forestier F, Tertian G, Catherine N, Pons JC, Tchernia G. Fetal platelet counts in thrombocytopenic pregnancy. Lancet 1990 Oct;336(8721):979-982.

18. Scioscia AL, Grannum PA, Copel JA, Hobbins JC. The use of percutaneous umbilical blood sampling in immune thrombocytopenic purpura. Am J Obstet Gynecol 1988 Nov;159(5):1066-1068.

19. Payne S, Resnick R, Moore TR, Hedriana HL, Kelly TF. Maternal characteristics and risk of severe neonatal thrombocytopenia and intracranial hemorrhage in pregnancies complicated by autoimmune thrombocytopenia. Am J Obstet Gynecol 1997 Jul;177(1):149-155.

20. Johnson JR, Samuels P. Review of autoimmune thrombocytopenia: pathogenesis, diagnosis, and management in pregnancy. Clin Obstetric Gynecol 1999 Jun;42(2):317-326.

21. Elezović I, Bosković D, Tomin D, Pilić Z, MikovićZ, Popović M, Knezević S, Sukalo M. Cesarean section combined with splenectomy in severely resistant immune thrombocytopenia. Acta Chir Iugosl 2002 Feb;49(3):51-54.

22. Sendag F, Kazandi M, Terek MC. Splenectomy combined with cesarean section in a patient with severe immunological thrombocytopenic purpura refractory to medical therapy. J Obstet Gynaecol Res 2001 Apr;27(2):85-88.

23. Hall S, McCormick JL, Greipp PR, Michet CJ Jr, McKenna CH. Splenectomy does not cure the thrombocytopenia of systemic lupus erythematosus. Ann Intern Med 1985 Mar;102(3): 325-328.

24. You YN, Tefferi A, Nagorney DM. Outcome of splenectomy for thrombocytopenia associated with lupus erythematosus. Ann Surg 2004 Aug;240(2):286-292.

25. Kuwana M, Kaburaki J, Okazaki H, Miyazaki H, Ikeda Y. Two types of autoantibody-mediated thrombocytopenia in patients with systemic lupus erythematosus. Rheumatology (Oxford) 2006 Jul;45(7):851-854. 